\title{
JLEET
}

Journal of Language Education and Educational Technology

Volume 6 No. 1, 2021

e-ISSN: 2502-3306

\section{The Effect of Project Based Learning on the Writing Competence of English Majors of Halu Oleo University}

\author{
Vill Janna Ningzi, Nurnia, M. Yazid A.R.G.
}

Halu Oleo University, Indonesia

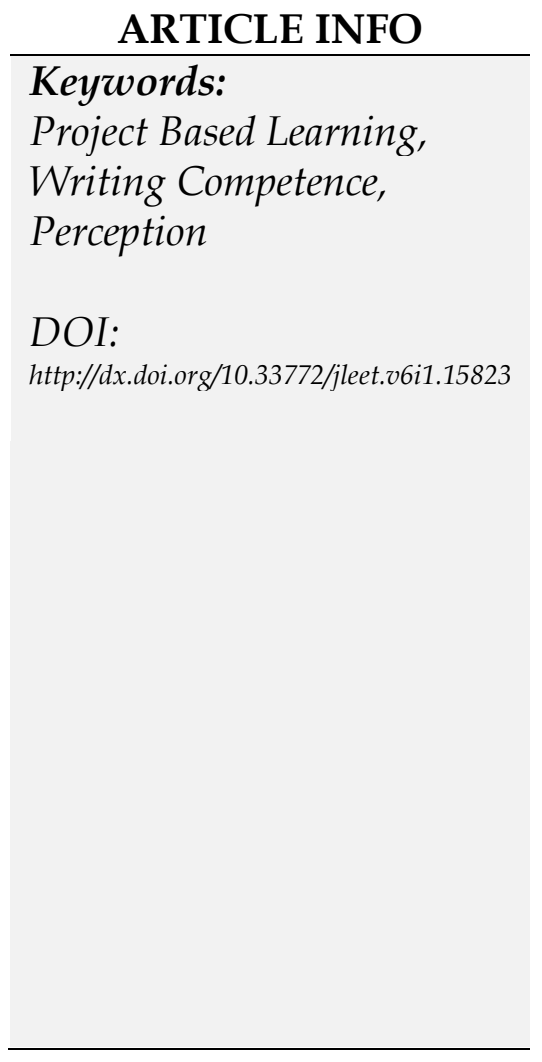

\begin{abstract}
This study aimed to investigate the effect of project based learning on students' writing competence and to investigate students' perception toward the implementation of project based learning. The study employed a quantitative research design. The subjects of the study were 48 English majors at Halu Oleo University. Data were collected by administering a writing test and a questionnaire. The researcher used paired sample $t$ test to examine the effect of project based learning on students' writing and the questionnaire to explore students' perception toward the application of project based learning. The findings of the study showed that project based learning had a significant positive effect on students' writing performance. By the same token, the result of the questionnaire also showed that the students had a positive perception toward project based learning. Overall, project based learning appears to positively impact on students' writing competence. Not only did the project promote social interaction among the students, but it also made the students active and deeply engaged in their learning.
\end{abstract}

\section{Introduction}

Writing is one way to communicate with each other where by one can express and share one's ideas, opinions, feelings, thoughts in the form of written communication by 
means of words, sentences and paragraphs (Raimes, 1983:76). Thus, writing plays an important role in both oral and written communication.

In English language learning, Writing is one of the language skills that must be mastered by language learners in addition to Listening, Reading, and Speaking. However, Writing is also known to be one of the most difficult and complex skills to be mastered by EFL students (Byrne, 1988; Heaton, 1990).

To develop writing skills, the students could bring the fact or their knowledge to be practiced in writing. However, writing is not easy simply because some students still have difficulties in developing paragraphs due to lack of vocabulary, grammar, spelling, etc. As Karani (2008) states that so many students are still faced with the problems in content, vocabulary and grammar when writing argument essays. To make matters worse, students' interest in writing has also been a major obstacle. Teachers can use teaching strategies or models to make students more interested in writing. In this case, teachers can apply project based learning which is also recommended in the 2013 Curriculum (Departemen Pendidikan Nasional, 2013). Project based learning can increase students' motivation, attract students' attention and give a sense of satisfaction (Blumenfeld at al., 1991).

Project based learning is a teaching method which is based on student centered learning. It is is a student-driven and teacher facilitated approach to learning (Bell, 2010). Thus, project based learning has mission to increase students' participation during teaching and learning process. Project based learning encourages students to be more active and creative. Students are expected to create a real thing that is based on teaching material. They are given opportunity to express their idea and develop their knowledge by producing a product. Projects undertaken by students can take the form of individual or group projects and are carried out within a certain period of time collaboratively, producing a product, the results of which will then be displayed and presented. Project implementation is carried out in a collaborative and innovative, unique way, which focuses on solving problems related to student life. Simply put, project based learning is part of instructional methods that are centered on students.

Project based learning has the potential to boost students' writing skill in the classroom. However, little research has been undertaken to study the extent to which project based learning could impact on students' writing achievement, as well as how such a method is perceived by the students. The present study seeks to fill this gap in research.

\section{Literature Review}

\subsection{Project Based Learning}

Project-based learning was introduced in the teaching and learning of English in the 21 stcentury. Project based learning model is a learning strategy where students must build their own content knowledge and demonstrate new understanding through various forms of representation (NYC Department of Education, 2009).

Project based learning is an instructional approach that contextualizes learning by presenting learners with problems to solve or product to develop (Poonpon, 2011). 
This model provides opportunities for students to determine their own projects to be done both in terms of formulating questions to be answered, choosing topics to be studied, and determining research activities to be carried out. Project based learning can be understood as "using authentic, real-world project based on highly motivating and engaging question, task, or problem to teach students academic content in the context of working cooperatively to solve the problem"(Barrel, Baron, and Grant's in Kemendikbud 2013:38). Project based learning is a teaching technique in which students are given a problem or challenge as a means of gaining new knowledge or skills where the teacher acts as a facilitator while students are required to be active in the learning process.

\subsection{The steps of the Project Based Learning}

According to Boss and Kraus (2013), the steps of the project based learning model are as follows: (a) Learning that begins with fundamental questions, namely questions that can stimulate students to enter in learning and linking the material to be taught with everyday life that is expected to be more easily understood by students; (b) Design project planning that is carried out jointly between the teacher and students who are negotiating about the rules of the game, as well as the tools and materials that will be used in completing a project; (c) Arrange a schedule of activities in completing the project together that contains the target implementation time, which is expected to be on time and on target; (d) Monitoring students and project progress, in at this stage the teacher must monitor (monitor) the activities of the students while completing the project, which is done by guiding and facilitating students in each process. The teacher is the responsibility in this process and outcome; (e) Testing Results, at this stage the teacher conducts an assessment aimed at measuring the achievement of the minimum completeness criteria that play a role in evaluating the progress of each student; (f) Evaluating experience, this stage is the final stage in this activity, teachers and students reflect on both individuals and groups. At this stage students are also asked to express their feelings and experiences while completing the project. Teachers and students conduct discussions in order to improve performance during the learning process, which in turn will find new findings.

Similar procedures were proposed by The George Lucas Educational Foundation (cited in Pratomo, 2010:26) and these procedures were used in the present study. The procedures are as follows. Firstly, start with essential question. The teacher starts the teaching and learning process by giving students essential questions. The questions must be relevant to the goals that the students must achieve during the project. The questions also must be related to the knowledge that the students construct and the topic must fit to their proficiency level. It ought to be related with students' daily life.

Secondly, design a plan for the project. The design of the plan contains the explanations of the rules of project development, the activities leading to the project accomplishment, the selection of the materials and tools needed for the project. The teacher gives students chance to participate by sharing their ideas on the project in order to make the project meet with the students' interest, capability, and expectation. 
Next, create a schedule. In this phase, the teacher and the students discuss the deadline of the end product that must be submitted. It also includes the time allocation in doing the project.

Then, monitor the students and the progress of the project. It is the most important stage in which the project development takes place. It is important since the success of the project accomplishment is determined by how well the students develop the project. At this stage, the teacher is required to play the role as monitor. The teacher is responsible for facilitating the learning process, guiding students during the process, helping students if they face difficulties and ensuring that the students are involved in the project.

Fifthly, assess the outcome. The teacher asks students to submit their project. The teacher collects and checks students' project. The teacher also related students' progress with the teacher instruction. Assessing the outcome allows the teacher to evaluate the students' achievement and the quality of teaching-learning process.

Finally, evaluate the experiences. In this last stage, the teacher and the students reflect on the activities and the project they have done. Allow for individual reflection, such as journaling, as well as group reflection and discussion (for example, validate what students have learned and makes suggestions for improvements).

\subsection{The Nature of Writing}

Writing is one of the four language skills (Listening, Speaking, Reading, and Writing) that students must learn. Writing has always appeared in the syllabus of English language teaching. Horwitz (2008:136) adds "writing is essential when the second language is needed for academic or professional purposes". Writing could help students learn because it puts together all the materials that have been taught such as grammar, vocabulary, structure, and get the students express their own ideas using this knowledge (Raimes, 1983).

Needless to say, the students need to be guided by the teacher as a facilitator to develop their writing skills and create a good piece of writing. Nunan (2003) states that writing is a process of thinking to find ideas, thinking how to write ideas, how to express feelings into writing, and how to arrange the ideas into sentences and paragraphs clearly. According to Brown (2001) writing is a process of thinking in which the written language is the result of the writers' thoughts. At times, the process of thinking takes a long time, the writers are asked to explore their knowledge, experiences, or memories to find and then determine a topic to write.

Writing is a process and it is influenced by the constraints of genres which have to be presented in the learning activities. Students who are writing within a certain genre consider a number of different factors such as the knowledge of the topic, the convention and style of that particular genre, and the context in which their writing will be read (Harmer, 2004). Writing is a process to express peoples' thoughts and ideas to others in a written form. It can be information, opinion, feeling, argument, explanation, and theories. Writing is an act communication between writer and reader via text. 
As mentioned earlier, Writing is a skill which must be taught and practiced. That is why, teaching writing is very important in the English class. Teaching writing is the activity to increase the students' learning of grammar and vocabulary (Harmer, 2004). Teaching writing to students is significant because it can reinforce students' language acquisition, support students' language and learning development, and help students master the basic skills of language (Harmer, 1998). In order to achieve the goals of teaching and learning, the teacher should observe some principles for teaching writing. According to Sokolik in Nunan (2003), there are four principles for teaching writing, they are:

a. Understand the students' reason for writing

b. Provide many opportunities for students to write

c. Make feedback helpful and meaningful

d. Clarify for yourself, and for your students, how their writing will be evaluated.

\section{Research Questions}

The present study was guided by the following questions:

1. What is the effect of project based learning on students' writing competence?

2. What is students' perceptions on the use of project based learning in teaching writing?

\section{METHODS}

This research applied a pre-experimental research design implemented in intermmediate writing class involving 48 students. Two kinds of instruments were applied in this research to collect data. The instruments were writing test and adapted questionnaire. Writing test was designed to assess student writing competence, whereas the questionnaire was used to elicit student perception of project based learning. Both instruments were pre- and post-tested. The pre-test was administered on Monday, October 12th 2020. The pre-test was the writing test in the form of recount text with the theme "Do The Students Have to Work Part Time?" in which students were required to write 250-300 words. Each student was given 60 minutes to write the argument text. This test was intended to gauge the students' writing competence before students received the treatment.

Following the treatment, students were exposed to project based learning over the period of four meetings taking place from October 19th to November 2nd, 2020 when learning how to write an argumentative essay. To begin with, the researcher introduced project based learning and how it is applied in a writing task. Having been familiar with project based learning, the students were then asked to complete a writing task by means of project based learning under the supervision of the teacher. A post-test (writing test and questionnaire) was then administered at the conclusion of the 4th meeting.

Student writing was then marked and the questionnaire results were entered into the SPSS application for data analysis. A paired-samples t-test was employed to examine possible differences between mean scores on pre- and post-tests. Frequencies, 
percentages, and descriptive analysis were employed to analyze the data from the questionnaires on students' perception toward project based learning.

\section{FINDINGS AND DISCUSSION}

\subsection{Findings}

Research Question 1. What is the effect of project based learning on student writing?

Table 1. Paired Sample t-test

\begin{tabular}{|l|l|l|l|}
\hline & Mean & t value & Sig. (2-tailed) \\
\hline Pair Pretest-posttest & 20.416 & 18.354 & 0.000 \\
\hline
\end{tabular}

The output of paired samples statistic showed that the mean of pre-test and post-test is 20.41667 which means that the different mean between two scores was 20.41667. The standard deviation is 7.70696. The standard error mean is 1.11240; it describes the accuracy as an estimate of the population mean. The smaller the standard error value, the better the sample because it represents the population enough. The lower difference is 22.65453, while upper difference is 18.17880. The result of $t$ test $=(18.354)$ with $\mathrm{df}=47$ and significant value $=(0.000)$. Since $p(0.000<0.05$, the null hypothesis should be rejected in favor of the alternative hypothesis. It can therefore be concluded that post-test scores are significantly higher than pre-test scores and that the application of project based learning significantly and positively impacts on student writing competenci on argumentative essay.

Research Question 2. What is student perception of project based learning?

\begin{tabular}{|c|c|l|l|}
\hline Item & Total Score & $\begin{array}{l}\text { Percentage } \\
\text { Level }\end{array}$ & Criteria \\
\hline 1 & 202 & $84.17 \%$ & Positive $(70 \leq \mathrm{Pc} \leq 84)$ \\
\hline 2 & 172 & $71.67 \%$ & Positive $(70 \leq \mathrm{Pc} \leq 84)$ \\
\hline 3 & 217 & $90.42 \%$ & Very Positive Pc $>85 \%$ \\
\hline 4 & 200 & $83.33 \%$ & Positive $(70 \leq \mathrm{P} \leq 84)$ \\
\hline 5 & 184 & $76.67 \%$ & Positive $(70 \leq \mathrm{Pc} \leq 84)$ \\
\hline 6 & 183 & $76.25 \%$ & Positive $(70 \leq \mathrm{Pc} \leq 84)$ \\
\hline 8 & 177 & $73.75 \%$ & Positive $(70 \leq \mathrm{P} \leq 84)$ \\
\hline 9 & 200 & $83.33 \%$ & Positive $(70 \leq \mathrm{Pc} \leq 84)$ \\
\hline 10 & 181 & $75.42 \%$ & Positive $(70 \leq \mathrm{Pc} \leq 84)$ \\
\hline Total & 131 & $54.58 \%$ & Negative $(40 \leq \mathrm{Pc} \leq 54)$ \\
\hline $\begin{array}{c}\text { Average of } \\
\text { perception level }\end{array}$ & 1847 & & \\
\hline & & $76.96 \%$ & Positive $(70 \leq \mathrm{Pc} \leq 84)$ \\
\hline
\end{tabular}


As seen from the above table, student responses have been classified into one of the three categories: very positive, positive and negative. Questionnaire item \#3 has been classified as "very positive", items \#1, \#2, \#4, \#5, \#6, \#7, \#8, and \#9 "positive", while item \#10 "negative". Thus, around $76.96 \%$ of the total responses have been positive and well received. In other words, the students enjoy project based learning.

\subsection{Discussion}

As mentioned earlier, the objective of the present study was two-folds; first, to examine the effect of project based learning on student writing skill and to scrutinise how such an approach to teaching is perceived by the students.

An assumption underlying the present study was that project based learning had a positive and significant effect on the students' writing achievement and the result of this study confirms this assumption. As mentioned earlier, the pretest score was 71.51 which then rose to 91.93 in the post-test - an increase of 16,42 - following the introduction of project based learning. A t-test further reveals that such an increase is statistically significant. This, in turn, suggests that project based learning is effective in improving students' writing. By the same token, an exploration of students' perception towards the implementation of project based learning also indicates that their perception has generally been very positive.

The finding reported above is in line with those of previous study, especially with the research conducted by Larasasti (2015) using project based learning with poster as the project. The author found that there was some improvement (as indicated by the gain score) in students' writing, encompassing improvement in the grammar, vocabulary, mechanics, fluency, and organization. Similarly, Marista (2016) also reported that project based learning gives students more opportunity to develop their writing skills and conclude that such improvement is attributed to the fact that project based learning enables students to explore and experiment with their ideas and conctruct their knowledge accordingly.

In addition to improving students' test scores, group activities which the students had during the project enhanced their interaction and involvement in the learning activities. Through group activities, the students were able to share their knowledge, information, and experience with each other in their attempt to finish the project. They were able to contribute to the project based on their expertise. As Mergandoller \& Larmer (2004) state that project based learning reflects an explicit commitment to help students learn not just content and organization, but also the skills they need to make use of their knowledge and to gain future knowledge such as communication skill, group participation and leadership skills. Arguing in a similar vein, Fragoulis (2009) states that project based learning promotes social learning that enhances collaborative skills in which case students are allowed to work together and they are able to contribute to the project based on their expertise. The group which consists of students with different levels of proficiency also encourages them to help and learn from each other. So, learning collaboratively helped the students to build a positive relationship among them. 
As far as students' perception towards project based learning is concerned, the average perception level is $76.96 \%$ categorized as a "positive" level. The finding is also in line with a previous study by Meechai Wongdaeng (2018) in which case he found that the students have a positive perception towards learning English through PBL, a finding identical to that reported in the present study.

\section{CONCLUSION}

The study has presented an overview of using project based learning for teaching writing and concludes that use of project based learning improves students' writing skills and that the use of such an approach to learning is well received by the students. In fact, students' responses towards the use of project based learning have generally been positive. An improvement in students' post-test scores has been attributed to students' collaboration in the process of constructing knowledge. This study has added more evidence to the existing literature pertaining to the merit of project based learning in language classrooms.

\section{References}

Bell, S. 2010. Project Based Learning for 21th Century: Skills for theFuture.

Taylor\&Francis Group, LLC

Blumenfeld, Philis C. et al. 1991. Motivating Project-Based Learning: Sustaining the doing, supporting the learning. Educational Psychologist, 26(3,4), 369-398.

Brown, H. Douglas. 2001. Teaching by Principle: An Interactive Approachto Language Pedagogy (2nd Ed). New York: Longman.

Byrne, Donn. 1988. Teaching Writing Skills. London: Longman Group UK.

Depdiknas. 2013. Permendiknas No.64 Tentang Standar Isi Pendidikan Dasar dan Menengah. Jakarta: BSNP.

Harmer, Jeremy. 1998. How to Teach English. Malaysia: Pearson Education Limited. Harmer, Jeremy. 2004. How to Teach Writing. Malaysia: Pearson Education Limited.

Heaton, John Brian. 1990. Writing Language Tests (New ed). United Statesof America: Longman.

Horwitz, Elaine Kolker. 2008. Becoming a Language Teacher: A Practical Guide to Second Language Learning and Teaching. USA: Pearson Education Inc.

Karani, E. 2008. Area of problems in writing recount text. JurnalPendidikan Inovatif, 4(1).

Krauss, J. \& Boss, S. 2013. Thinking through Project Based Learning: Guiding Deeper Inquiry. Thousand Oaks, CA: Corwin

Kementrian Pendidikan dan Kebudayaan. 2013 Model Pembelajaran Berbasis Proyek/Project Based Learning.

Nunan, David. 2003. Practical Language Teaching. New York: The Mc Graw Hill Companies Inc. 
NYC Department of Education. 2009. Project-Based Learning: Inspiring Middle School Students to Engage in Deep and Active Learning. New York.

Poonpon, Kornwipa. 2011. Enhancing English Skill through Project Based Learning. The English Teacher Vol. XL: 1-10 Journal. (pp. 1-10).

Pratomo, Bayu. 2010. The Use of Project Based Learning to Improve The Students' Writing Skills at Clas VII F of SMP Negeri 7 Magelang. Yogyakarta: State University of Yogyakarta.

Raimes, Ann. 1983. Technique in Teaching Writing. Oxford: Oxford University Press. 